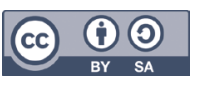

UDK 78(474.2)"1970-1991":78.03

DOI: $10.4312 /$ mz.54.2.141-163

\title{
Anu Veenre
}

Estonian Academy of Music and Theatre

Estonska akademija za glasbo in gledališče

\section{Beyond Polystylism: Blurring the Boundaries between Different Musics in late-Soviet Estonia}

\section{Onkraj polistilizma: Brisanje meja med različnimi glasbami v pozni sovjetski Estoniji}

Prejeto: 1. avgust 2018

Sprejeto: 20. avgust 2018

Ključne besede: pozni socializem, glasbeno zgodovinopisje, polistilizem, neuradna glasba, živeti vnye

\section{IZVLEČEK}

Razvoj estonske glasbe in glasbenega življenja v poznem sovjetskem obdobju je mogoče interpretirati v smislu poizkusov glasbenikov in skladateljev, da bi se odtujili sovjetskemu sistemu in ideologiji, ki je bila ta čas pripisana umetnosti. Članek raziskuje vzroke in različne obraze tega procesa s pomočjo analize aktivnosti različnih glasbenih skupnosti in njihovega vpliva na razvoj umetnostne glasbe. Razpravo zamejuje koncept polistilizma, medtem ko sta koncepta življenja v vnye in neuradne glasbe, kot ju za raziskovanje sovjetskega obdobja predlagata Aleksej Jurčak (2006) in Peter Schmelz (2009), uporabljena za razpravo o zvezah med glasbo in politiko.
Received: $1^{\text {st }}$ August 2018

Accepted: $20^{\text {th }}$ August 2018

Keywords: late-Socialism, music historiography, polystylism, unofficial music, living in vnye

\section{ABSTRACT}

Developments in the Estonian music and musical life of the late Soviet period may be interpreted as attempts on the part of musicians and composers to alienate themselves from the Soviet system and from the ideology that was attributed to the arts at the time. The article examines the reasons for and the various facets of this process by analysing the activities of the different musical communities of the time and the influence of these on the development of art music. The discussion is framed using the concept of polystylism, the concepts of living in vnye and unofficial music as proposed by Alexei Yurchak (2006) and Peter Schmelz (2009) for examining the Soviet era are used to discuss the relations between music and politics. 


\section{Introduction}

The Estonian music culture of the late Soviet period can be researched and interpreted from a number of different perspectives. This article focuses on one of the more prominent trends in Estonian music from the mid-1970s till the end of the 1980s - music that incorporates elements from different musical styles and practices - discussed through the concept of polystylism. More commonly understood as an umbrella term for a type of compositional-technical strategy that has varied between authors, regions and periods of time, this article examines polystylism also as a cultural phenomenon. The study therefore also outlines and discusses the socio-political circumstances and more general cultural contexts that either gave rise to or fostered the emergence of this tendency. To this end the characteristics of the different musical communities of the time - i.e. classical, folk, pop-rock, early music, and those interested in non-Western musical traditions - and the communication between them are examined. Referred to as different musics, these above-mentioned styles and practices individually signify the broadest and most general categories of musics which, in addition to their more or less distinctive musical idioms, have traditionally been differentiated from one another by their different learning modes (educational aspects) and forms of consumption (including performance practice). Compared with the 2000s, when the borders between these musics became more or less blurred in several aspects and fields of music, the 1970 s can be marked as the decade when this process of blurring first became noticeable. In Estonia, besides the more general postmodern environment, several other factors in social life and the political sphere conspired to give rise to such tendencies. This decade has thus been selected as the historical starting point for the article.

From the perspective of music historiography, this article aims to contribute to two fields of research: on one hand, to the search for a methodological approach for discussing the developments in different musics in one and the same historical narrative; and, on the other, to complement the studies of late Soviet music in a discourse that focuses on the interconnections between music and the socio-political context. During recent decades, in fact, there has been a growing tendency in musicological studies to call into question the tradition of discussing music according to the styles mentioned above. In music history writing and in musical composition itself the tendency has been to try to avoid any kind of categorization, but instead to seek new approaches and methodological standpoints for narrating the story of all musics more or less simultaneously. ${ }^{1}$ Considering the music research of the latter half of the $20^{\text {th }}$ century beyond - and taking into account the changes that have taken place in musical life since then at an institutional level - the need for such a shift in historical musicology seems even more urgent. In the context of late Soviet Estonia, taking the socio-political context of the time as a starting point for musicological research, several issues stand

1 For example, with regard to the most in-depth music histories and dictionaries available in English - the Grove dictionary and the Cambridge series of music history, for example - there are examples of including different musics as equally valuable subjects into one and the same music history volume; however, they have generally been studied as separate topics in different chapters and/or entries. See Nicholas Cook and Anthony Pople, eds., The Cambridge History of Twentieth-Century Music (Cambridge; New York: Cambridge University Press, 2004) and Grove Music Online, www.oxfordmusiconline.com/grovemusic. 
out as affecting in equal measure the developments in different spheres of musics at the time, eventually blurring the boundaries between these musics and, consequently, offering the possibility of a historical narrative that combines different musics.

As far as the theoretical background is concerned, the first part of the article examines the discourse of the late Soviet era. In this respect, the present research draws primarily on studies by Alexei Yurchak ${ }^{2}$ and Peter Schmelz ${ }^{3}$, and aims to discuss the applicability of their approaches to the Estonian context of the time. Additionally, as a part of the theoretical framework, the subsection that follows examines the concept of polystylism in an attempt to test its applicability to describing both the tendencies in music and musical life.

The second part of the article offers an overview of research into different musics in Estonia during the 1970s and 1980s. Because of their more direct relationship with and influence on developments in art music, four types of movements are considered: the beginnings of the early music movement, the folk music movement, some Estonian pop and rock music, and the interest in non-Western musical traditions. The section on non-Western music serves as a case study, the discussion here relying on the writings and music of the composer Kuldar Sink (1942-1995). In addition to their reflection of non-Western musics, these sources are very telling with regard to the composer's own attitude towards the ideological pressure on the contemporary (Estonian) art music of the time.

\section{Music in Late-Soviet Estonia: A Historiographical Approach}

In the years 1940-1991 Estonia was occupied by the Soviet Union and formed a part of the Union of Soviet Socialist Republics. ${ }^{4}$ Due to the prevailing totalitarian system, the historiography of Estonia with regard to the latter half of the $20^{\text {th }}$ century, music included, could not escape a political dimension. In this respect, Estonian historian Tõnu Tannberg has aptly summarised the typical understanding of the era: "Cut off from the Western world, Estonia was subjected to the extensive Sovietization of community life and the muzzling of intellectual and spiritual life, the suppression of resistance, the implementation of repressions and the introduction of a Sovietstyle controlled economy in the postwar years." ${ }^{5}$ Another commonly accepted understanding concerns the partial softening of the regime after the death of Stalin (known as the Thaw of the 1960s) followed by the period of Stagnation (in the 1970s and 1980s) and culminating in the years of perestroika from around 1987 till the disintegration of the Soviet Union in 1991. Nevertheless, it is a well-known fact that this

2 Alexei Yurchak, Everything was forever, until it was no more: the last Soviet generation (Princeton; NJ: Princeton University Press, 2006).

3 Peter J. Schmelz, Such freedom, if only musical. Unofficial Soviet Music during the Thaw (Oxford: Oxford University Press, 2009).

4 In the years 1941-1944 German occupation of Estonia took place. On Estonian political history see http://www.estonica.org/ en/History/.

5 Tõnu Tannberg, "Foreword" in Behind the Iron Curtain: Soviet Estonia in the Era of the Cold War. Tartu Historical Studies, Volume 5, ed. Tõnu Tannberg (Frankfurt am Main: Peter Lang Verlag, 2015), 7. 
periodization varies according to the different regions of the Soviet Union as well as to the various spheres of life. Though it refers to a different period (the post war years), the above extract indicates all the more central themes that Sovietology has traditionally relied on, and still does: isolation from the Western world, the application of Soviet ideology to all spheres of life, resistance to the same regime, and different forms of oppression. Thus, to a certain extent it may be claimed that, similarly to the implications of Cold War rhetoric, the historiography of the Soviet era, too, has long been characterized through oppositions. On the one hand, this oppositional character reveals itself in the conceptual confrontation between the conditions of life in the West and in Eastern Europe, showing the former in a good light and comparing it favourably with the latter. On the other hand, such an approach has caused the rather rigid division of the (creative) acts and processes of the time in the countries of the Soviet Union, characterizing them either as being collaborative or as opposing the system (reflecting the binary distinction between activism and dissidence).

In this respect, Russian anthropologist Alexei Yurchak's approach to the era, first discussed in his book about the last Soviet generation, marked a real break-through, affecting many writers from different disciplines from that time on. According to Yurchak, "dichotomies such as oppression and resistance, truth and lies, official culture and unofficial culture, the state and the people, public self and private self overlook the complex meanings, values, ideals, and realities that constituted the Soviet system and, defying clear-cut divisions, existed both in harmony with the state's announced goals and in spite of them". ${ }^{6}$ In order to describe and research the complex nature of people's mental and spiritual attitudes, as well as the practical way of living of many people in the late Socialist period, Yurchak returns to the concepts of vnye - which literally translates from Russian as "outside" -, and deterritorialization. Referring to vnye as a dominant mode of living during the late Socialist period, Yurchak defines it through a particular relation to authoritative discourse: "[B]eing vnye - that is, occupying a position that was simultaneously inside and outside the rhetorical field of that discourse, neither simply in support nor simply in opposition of it. This relation actively defied boundaries and binary divisions, becoming a dynamic site where new meanings were produced."7

In music studies, too, the concept of being vnye has become useful. For example, despite many composers' more or less open aversion to Soviet ideology and the system, at the same time they belonged to and participated in the work of different state institutions (e.g. the Composers' Union, the Philharmonics, the Conservatory). And though it may be claimed that belonging to state institutions was an inevitable part of life if one was to survive socially and financially in Soviet Estonia, this fact nevertheless served to reduce the spread of dissidence.

At the same time, the concept of deterritorialization, in the context of Soviet cultural life signifies the kind of milieus, lifestyles and interests that many musicians were involved with which "were focused on the forms of knowledge, codes and meanings that were not articulated in authoritative discourse, but instead came from various

6 Yurchak, Everything was forever, 283.

7 Ibid., 288. 
imaginary 'elsewheres' - such as, theoretical science, ancient languages, nineteenthcentury poetry, religion, Western rock music, and so on. The meaning of these milieus and their occupations cannot be reduced to the opposition to the system. Rather they were in a deterritorialized relationship toward it, locating themselves simultaneously inside and outside cultural practices, ethics, and ideals." ${ }^{8}$ Many of the interests shared by several Estonian composers and musicians of the late Soviet era may also be associated with such imaginary "elsewheres": Studies in early music (and this included religion), folk, rock, and non-Western musics - a phenomenon that will be considered in greater depth later in this paper - were all supported by the state in their own way, yet a closer involvement in these fields also made it possible for musicians to alienate themselves to a certain extent from the regime and thus to live in vnye.

With regard to music studies, Yurchak's approach has been most thoroughly elaborated by the American musicologist Peter Schmelz, firstly in his seminal book Such freedom, if only musical: Unofficial Soviet Music during the Thaw. ${ }^{9}$ Taking as his examples selected Soviet composers born around $1930,{ }^{10}$ Schmelz meticulously analyses the music and events of the musical Thaw. As a central concept, the term "unofficial" is used to bring together the characteristics of vnye and deterritorialization at the same time, especially with regard to the field of music. ${ }^{11}$ This paper examines whether and under what circumstances the concept of unofficial music applies to the Estonian music of the late 1970s and 1980s, i.e. that of the period following the musical Thaw. Broadly speaking, two dimensions of the phenomenon are taken into account in discussing unofficial music in the Soviet Union: firstly, the organization of the compositional material in strictly musical terms; and, secondly, all the circumstances relating to the processes of creating and disseminating the works - in other words, everything that concerns the social dimension of being a composer. Relying on Schmelz's study, the music-specific meaning of the unofficial is finely encapsulated by Kevin Karnes in his book on Arvo Pärt's Tabula Rasa: "As it has been since the 1930s, 'official' music of the period remained locked within the uncertain confines of Soviet socialist realism, as promoted by often nameless officialdom and policed by the Ministry of Culture and the Union of Soviet Composers. Such music was to be broadly accessible in terms of its tonal and melodic language, and it was to affirm, in its subjects and texts, sanctioned political ideology and the greatness or promise of the Soviet state or peoples. In contrast, unofficial music was often esoteric in terms of its construction, and it usually avoided sanctioned themes."12

When talking about the Estonian music of the Thaw period, there are examples of works that may be regarded as unofficial due to their compositional material, which contradicts socialist realism in strictly musical terms. The trends in the Estonian music

9 Schmelz, Such freedom.

10 In particular, Schmelz focuses on the activity of Edison Denisov (1929-1996), Sofia Gubaidulina (b. 1931), Arvo Pärt (b. 1935), Alfred Schnittke (1934-1998), Valentin Silvestrov (b. 1937), and Andrey Volkonsky (1933-2008).

11 The author explains: "Fully aware of the binaries suggested by "unofficial," I have cautiously chosen to use this term throughout. With its emphasis on the power structures - and, therefore, the inherent tensions - of Soviet life, it proves less problematic than terms such as "dissident", "outsider," "nonofficial," "nonconformist," "underground," or even "avant-garde," all previously favored by writers occupied with the music, art, or literature of the time." Schmelz, Such freedom, 20

12 Kevin C. Karnes, Arvo Pärt's Tabula Rasa. Oxford keynotes (New York: Oxford University Press, 2017), 18. 
of the 1970s and 1980s, however, leave no space for such a contradiction in this respect. Nevertheless, the above-mentioned "social dimension" of "unofficiality" in music still had a certain role to play in late Soviet Estonia: "Whereas official music was purchased by the state, performed under the auspices of philharmonics (regional organizations responsible for official concert programming), and published by government-run firms, unofficial music, typically premiered in composers' residences, private clubs, or university lecture halls, and it often remained unpublished, generating no income for its composers." 13 Here too, the concept of unofficial must be applied to the late Soviet Estonian context only with caution, and with some modifications.

\section{Combining Different Musics: Polystylism Revisited}

In addition to focusing on its compositional-technical nature, polystylism may be discussed as a cultural phenomenon reflecting the socio-political context and processes of the time. The Estonian new music of the late Soviet period provides a convincing example of such an interpretation.

The term polystylism is most commonly used in relation to the music and composers of the former Soviet countries with reference to the music from the (mid-)1960s till the end of the 1980s. Despite its manifestation in different forms and contexts, in its most general terms polystylism refers to the compositional-technical approach of classical music composers who incorporated into their works elements originally associated with other musical realms - styles or practices taken either from the past or from contemporary sensibilities. Irrespective of any specific compositional-technical approach, however, there are two questions that may be asked when discussing any type of polystylistic writing: first, the matter of "what" types of musics have been combined together; and, secondly, "how" this combining process has been (compositional-)technically carried out. With regard to both these aspects, significant changes took place in the polystylistic writing of Estonian composers around the mid-1970s. Viewing these changes - or rather, this turn in polystylistic writing - as a reflection of the socio-political situation and of the developments occurring in musical life at the time contributes to an understanding of polystylism as a cultural phenomenon; this will be considered in more depth in the following paragraphs. ${ }^{14}$

The "what" layer of polystylistic writing is closely related to questions of time and place in music: manifested either in the form of direct quotations or through more general allusions, the use of elements that usually feature in historical styles or genres in a new composition has the potential to evoke the historical dimension of time. References to the genres and styles belonging to the composer's contemporary world, on the other hand, direct the listeners' attention to the present music culture. Considering

13 Karnes, Arvo Pärt's, 18.

14 Considering the articles on former Soviet countries in the Grove dictionary, for example, polystylism as a compositionaltechnical trend from the 1970 s on is mentioned in the entries on the art music of Slovenia, Ukraine, and Georgia. Apart from the article on Slovenia, which mentions this tendency in the context of the postmodern situation, in these texts no further attention is paid to the wider cultural or socio-political context of the time. See "Slovenia," "Ukraine," and "Georgia" in http:// www.oxfordmusiconline.com/grovemusic, accessed March 25, (2018). 
the historiography of Soviet music, greater attention has generally been paid to the historical dimension of the phenomenon, largely due to the music and influential writings of Alfred Schnittke, who coined the term "polystylistics" back in the $1970 \mathrm{~s}^{15}$. Although there are examples in Schnittke's music encompassing elements from contemporary styles and genres, his music is mostly associated with an idea phrased by the composer himself as consisting of invoking "the scents and shadows of other times in music." 16 Such has been the case with Estonian music too, where the historical narrative emphasizes the role of some of Arvo Pärt's polystylistic works of the 1960s, such as Pro et contra (1966) and Credo (1968). However, the definition of polystylism is not restricted to the use of the classical music legacy, but embraces other - more contemporary - musics too. In this respect, Schmelz outlines the growing importance of pop and jazz music for the younger generation of Russian composers from the mid-1970s on. ${ }^{17}$ In Estonian professional music, at the same time, the relations with and influences of early music, folk, rock, and non-Western musics grew in popularity. Easily associated with a more general postmodern situation that stresses the role of stylistic plurality, Estonia did not, of course, stand alone in these developments. However, similar tendencies across different regions may have had different "backgrounds", and they are thus worth discussing. For example, in the context of the Estonian musical life of the time, it is justified to refer to the reflections of early music and folk music in new compositions as a phenomenon that stemmed from the realms of contemporary music, for both the early music and the folk music movements played a significant role in Estonian musical life at the time.

With regard to the question of "how" different musics have been combined together in polystylism, one may also think in binaries: musical material may use and combine elements from different musics either eclectically - in a form of contrasting juxtapositions of different elements (manifested in its most rigid form as a type of collage) -, or it may aim to synthesize originally different sound idioms with the purpose of "blurring the boundaries" more smoothly. In this respect, too, the presence of different, more or less inseparable practices or styles within a single piece of music is a phenomenon which - compared to the 1960s - has tended to grow in importance in Estonian music during and after the 1970s.

In particular, the Soviet polystylism of the (late) 1960s typically presents the use of various styles in the form of severe juxtapositions - stylistic oppositions between avant-garde techniques and tonal styles, for example - which, in many cases, are discussed with reference to composers' creative crises, reflecting their relations and/or attitudes toward society or academicism. ${ }^{18}$ For example, referring to Schnittke's Second Violin Concert Quasi Una Sonata from 1968 as a "work full of frustration", Schmelz points out: "In this it reflected not only the musical situation but also the upheavals and

15 Schnittke formally presented the idea of polystylism in his paper "Polystylistic Tendencies in Modern Music" at the Seventh International Music Congress held in Moscow by UNESCO's International Music Council on 8 October 1971. Schmelz, Such freedom, 255. For its publishing history and translations into English, see Schmelz, Such freedom, 366-367.

16 Alfred Schnittke, "Polistilisticheskie tendentsii sovremennoi muzyki," in Besedy s Alfredom Shnitke, ed. Aleksandr Ivashkin (Moscow: RIK "Kul'tura," 1994), 143-44. Quoted in Karnes, "Arvo Pärt's," 28.

17 Schmelz, Such freedom, 296.

18 On this topic, see chapter 6 "From Abstraction to Mimesis, from Control to Freedom: Pärt, Schnittke, Silvestrov, and Gubaidulina" in Schmelz, Such freedom, 216-274. 
mounting repressions of contemporary Soviet society and politics." ${ }^{19}$ And even in the works of the 1970s where the mixture of musical styles has far greater implications, the "dramatic mixture of styles" reflecting the "contrasts of contemporary life" remained. ${ }^{20}$

This is the point where developments in Estonian polystylism differ from those in Schnittke's music. In what may surely be understood partly as a generational turn, composers born around the 1950s in Estonia never use the mixture of different styles in a "dramatic" manner. In this respect, developments in Estonian music seemed to be more akin to those of (Western) Europe and America. For example, to quote the entry in the Grove dictionary about the symphony: "The overwrought intensity of much Russian polystylism has a tone distinctly remote from the disengaged and objective attitude that characterized European and American brands of stylistic pluralism in the 1970s and 80s."21

\section{Different Musics in Late-Soviet Estonia}

With reference to the periodicization of the Soviet era, Peter Schmelz argues that the musical Thaw ended no earlier than the mid-1970s. In his reasoning, the author outlines the following aspects: the generational change, the gradual relaxation of restrictions in performing (formerly) unofficial music, and the intensification of contacts with the West. ${ }^{22}$ Though given primarily with reference to Russia, all these factors apply in principle to the Estonian situation as well. First and foremost, in Estonian music history the 1970 s is seen as a decade when a new and very influential group of young composers, all born around 1950, came of age. The compositional approach of many of these composers illustrates the shift in polystylistic thinking described above - namely, from the historical dimension to the contemporary, and from eclecticism to synthesis. These developments are largely associable with those of the broader musical life of the time. The following paragraphs therefore offer some insights into the early music movement, the folk music revival, pop and rock music, and the growing interest in non-Western traditional music.

\section{The Early Music Movement}

Similarly to the changes in art music, many of the new trends that emerged in the musical life of Estonia in the 1970s also had their equivalents not only in other Soviet countries but in Western Europe as well. However, due to their emergence from a different socio-cultural context, some of these tendencies were filled with different

19 Schmelz, Such freedom, 254

20 Schmelz, Such freedom, 308.

21 Charles Wilson, "Symphony. 11. The survival of the symphony" in Grove Music Online, accessed March 6, 2018, http://www. oxfordmusiconline.com/grovemusic/view/10.1093/gmo/9781561592630.001.0001/omo-9781561592630-e-0000027254.

22 Schmelz, Such freedom, 295-297. Schmelz also outlines another three more concrete musical events from the mid-1970s that had (a more symbolic) importance in this respect: The emigration of the unofficial composer Andrey Volkonsky from Soviet Russia to the West in 1973, the premiere of Alfred Schnittke's First Symphony in 1974, and lastly - as a more metaphorical aspect -, the death of Dmitriy Shostakovich in 1975. Schmelz, Such freedom, 295-297, 323. 
"content". ${ }^{23}$ In this respect, the early music movement that developed rapidly in Estonia from the beginning of the seventies offers a good example. In addition to the unofficial gatherings of musicians, composers and historians at the time, the first early music ensembles - Viljandi Linnakapell and Hortus Musicus, both of which were related to the "pre-Bach" repertoire - were established in Estonia in 1971 and 1972 respectively. ${ }^{24}$ Much of the activity of these ensembles in the late-Soviet period illustrates the situation regarding the contact of Estonian musicians with other Soviet countries as opposed to Western Europe. For example, the Moscow early music ensemble Madrigal, founded by Andrey Volkonsky in 1964, had close contacts with Estonian musicians and thus served as a role model for them. ${ }^{25}$ At the same time, the historical performance practice movement with which early music communities were largely associated at the time in Western countries remained largely unknown to the Estonian music audiences, whose experience was primarily of musicians related to the conservatory and concert organizations. In this respect, for example, the first public discussions appeared in the press around 1985, in relation to the anniversaries of Schütz, Bach and Handel. ${ }^{26}$ At the same time, as an act of deterritorialization, the early music movement in Estonia was concerned with exploring a new (musical) territory, thus offering an escape from the Soviet world of constant control and dictation. Therefore, following some other model or ideology such as historically "informed" - or, more particularly "authentic" - performance practice would in principle have contradicted the very essence of the movement itself, that is, to the desire to alienate oneself from the system and not to have to conform to any rules. More concretely - and in this respect similarly to their colleagues in the West - the early music movement in Estonia alienated itself not only from the Soviet system, but also from the academic world as such: dedicating themselves primarily to the repertoire of the mediaeval and Renaissance eras, many of the qualities attributed to these musics were unknown in academic circles, and even in contrast to them (the different approach to the score, improvisational aspects, instrumentation, and so on). ${ }^{27}$ Nevertheless, as the hallmark of the era, this alienation from the system

23 Considering the relations between the arts and society from the perspective of opposition, punk music would be the most extreme example of this: both in the West and in Eastern Europe, punk served as a social protest; however, whereas in the West the protest was directed toward capitalism and consumerism, in the Soviet countries punk served as a protest against the communist regime. In an Estonian context, punk music did not have any influence on academic music, and therefore the topic is not included in the discussion that follows.

24 Such gatherings took place under the leadership of the composers Heimar Ilves (1914-2002) and Heino Jürisalu (1930-1991), for example. Early music was also taught and discussed by the flutist Kaljo West (1924-2008) and music historian Toomas Siitan (b. 1958).

25 Madrigal was the ensemble of Moscow State Philharmonic Society that also gave a few concerts in Tallinn in the late 1960 s. Before emigrating to the West in 1973, Andrey Volkonsky was forced to sell most of his books and scores. The young Andres Mustonen bought a portion of these for Hortus Musicus. More on Volkonsky's departure see Schmelz, Such freedom, 297-302.

26 In this respect, the articles by a young music historian Toomas Siitan about the music of Heinrich Schütz and Johann Sebastian were of particular importance. Siitan also translated and commented the texts of Nikolaus Harnoncourt to Estonian readers. All these articles were published in the cultural magazine Teater. Muusika. Kino between 1984-1987. Siitan was also among the first ones in Estonia to draw parallels between the early music idioms and different trends of the $20^{\text {th }}$ century music, a phenomenon that will also be considered in the following paragraphs. See Toomas Sitan, "Vana muusika uues muusikas," ["Old music in new music,"] Teater. Muusika. Kino, no. 6 (1984): 30-37.

27 Today Hortus Musicus still performs under the direction of Mustonen and is the oldest continuously working ensemble in its field in Eastern Europe. Whenever the members of this ensemble happen to talk about the history of its activity, the oppositional role to the Soviet system is mentioned. Also, the ensemble has never associated their activity with strictly historically informed, or "authentic", performance. See Hortus Musicus' webpage, https://concert.ee/kollektiiv/hortus-musicus/. 
- or, living in vnye - also worked in some sense as a contribution to it: in 1976 Hortus Musicus became one of the state ensembles of the State Philharmonic Society - that is to say, as official an ensemble as it was possible to be. Belonging to the Philharmonic guaranteed the musicians a regular income, a lively concert activity, and recording sessions with Melodiya. Nevertheless, at the same time it also meant following a prescribed repertoire. Andres Mustonen, the founder and leader of the ensemble up to the present day, has recalled that Hortus Musicus was not allowed to perform church music; despite this, however, the musicians associated their activity with religious ideas: "People are not stupid inside, everyone has a sense for truth and purity. Even when we were playing some secular piece, the listener could detect its true nature - the turning toward 'elsewhere' -, though we were told that you cannot make church music. The ray of your spiritual approach is what accounts. If it is bright or white - or, let us say, of the world of angels - then no matter what you do, it is religious." 28 Thus, regardless of the restrictions at the level of the Soviet system, religious topics were "in the air" among the musicians and composers of the time. Viewed as a part of religious life in Soviet Estonia, the activity of Hortus Musicus indicates the ambiguity surrounding the phenomenon. As Atko Remmel's research into the religious policy of the Estonian SSR shows, it was not until the policy of perestroika in 1988 that "religion once again began to be considered a (more or less) normal aspect of social life." ${ }^{29}$ Until that time (as Tõnu Tannberg concludes from Remmel's work), "[f]ormal religious freedom was preserved in the Estonian SSR, but in practice, believers and congregations faced all manner of direct and indirect obstructions." ${ }^{30}$ In the context of music, this meant that while sacred music was, of course, performed in late-Soviet times, it was not discussed in public; therefore, dedicating oneself to this field was associated with a form of resistance to the system. In Tannberg's words, "the church also filled the role of a distinct kind of spiritual opposition in Soviet society" ${ }^{31}$ As for the early music enthusiasts, their involvement with religious institutions was less direct, so that, rather than seeing their activities in terms of "opposition" to the system, their relation to the Soviet system in this respect could be interpreted in terms of living in vnye.

As far as the music performed was concerned, Mustonen has recalled that the only more concrete prescription regarding the repertoire of Hortus Musicus was that in addition to "old" music they should also perform "new" music. ${ }^{32}$ Cooperation with contemporary Estonian composers was welcomed, and since 1975 the ensemble has commissioned music from different Estonian composers with increasing regularity. In relation to the late Soviet era, such music included compositions by Raimo Kangro (1949-2001), Arvo Pärt (b. 1935), Lepo Sumera (1950-2000), Peeter Vähi (b. 1955), and Erkki-Sven Tüür (b. 1959). All these works indicate the use of early music instruments, but at the same time they also all reflect several other features that can be associated with early music. Varying according to the composers and the individual works, the

28 Kadri Hunt, "Retk aednike juurde. Hortus Musicus 30," ["Expedition to the gardeners,"] Muusika no. 9 (2002): 4.

29 Atko Remmel, "(Anti)-Religious Aspects of the Cold War," in Behind the Iron Curtain: Soviet Estonia in the Era of the Cold War Tartu Historical Studies, Volume 5, ed. Tõnu Tannberg (Frankfurt am Main: Peter Lang Verlag, 2015 ), 390.

30 Tannberg, "Foreword," 14.

31 Ibid.

32 Hunt, "Retk aednike juurde," 7. 
diatonic scales, rhythmic patterns, and the forms and/or improvisational aspects intrinsic to early music appear in these compositions in distinctive combinations with each composer's own contemporary compositional style. On the one hand, from the perspective of a composer there is nothing more natural than being inspired and even influenced by the specific qualities of the musicians who commission the music. And with respect to the situation in late Soviet Estonia, collaboration with Hortus Musicus also offered the opportunity for composers to alienate themselves from the Soviet system and to gain a hint of the taste of living in vnye.

Owing to the popularity of the ensemble, this new or alternative (musical) world that Hortus Musicus created with their activities reached wide audiences. Together with the new music composed especially for the ensemble, there can be no doubt that the activities of Hortus Musicus played a significant role in the development of Estonian contemporary music in more general terms, involving also a contribution to the tendency of polystylistic writing in its broadest sense towards the blurring of the boundaries between different styles of musics.

As far as more general trends in Estonian contemporary music are concerned, in 1982 Estonian musicologist Mare Põldmäe outlined the following features: a preference for consonant sounds; ${ }^{33}$ in orchestral music, timbers are predominant and thus, percussion instruments (such as celesta, xylophone, vibraphone) are used a lot; a preference for static dramaturgy rather than dramatism; a preference for a descriptive as opposed to a conflicting character; and the extensive use of a background-like texture, while the importance of melody and harmony in their former sense are minimized. ${ }^{34}$ Apart from the background-like texture, perhaps, all these features can be associated with - but not limited to - the influence of early music. However, recognizing the preference for consonant sounds as part of a broader tendency in contemporary classical music world-wide, Põldmäe refers to the music of Kancheli, Terteryan and Schnittke as examples. She also points out that Estonian music seems to walk this path less painfully than others but fails to provide any argument evidence for this. It is worth mentioning, however, that as well as the early music movement there were other contemporaneous movements under way in Estonia at the time which also shared the musical idioms and aesthetic values intrinsic to the development of art music.

\section{Folk Music and Contemporary Composers}

Another series of issue that can be observed in relation to the discourse of the authorities in late Soviet Estonia concerns the folk music movement, as manifested in the activity of folklore ensembles, the use of folk tunes in art music, and the more general influence of folk music idioms on contemporary composers. Regarding the

33 Here, Põldmäe uses a word "heakõlalisus" that literally translates as "something that sounds well, is pleasant"; regarding the music under discussion this trend is associated in musical terms with the use of consonant sounds; it is a music retrospectively associated with different stylistic currents of "new tonality".

34 Mare Põldmäe, "Mõeldes möödunud muusika-aastale," ["Thinking about the yesteryear in Music,"] Teater. Muusika. Kino, no. 2 (1982): 76. With regard to the year 1981, Põldmäe attributes these features to the music of Eino Tamberg (Violin Concerto), Lepo Sumera (First Symphony and Pantomime), Alo Põldmäe (Violin Sonata), and René Eespere (Ave Mater). 
activity of the folklore ensembles, there were two types of these active at the time, distinguishable from one another for their different kinds of repertoire, and hence for their different reception among contemporary composers and their influence on the music of the latter. For example, in June 1977 the activity of the folklore ensembles was discussed at a meeting of the Estonian Composers' Union folk music committee. The committee consisted primarily of professional composers and (ethno-)musicologists, and its activities were covered by Urve Lippus in a monthly journal Keel ja Kirjandus. In this text Lippus outlines two types of folklore ensembles existing in Estonia at the time (both in the field of music and dance): those which performed authentic folk music, and those whose approach was more estrada-like, i.e. performing repertoire that consisted of folk music arrangements, transcriptions, and pieces composed by (professional) composers in a folk-like manner. According to Lippus, the members of the commitee - including Veljo Tormis ${ }^{35}$ - preferred the activity of the former over the latter and shared the opinion that "by no means can these ensembles be advertised as performers of authentic Estonian folk music or dance." ${ }^{36}$ Differentiating between the authentic and estrada-like folk musics was a crucial topic for composers at the time. Thus, from the composers' perspective, pointing out the conceptual difference between these ensembles and their repertoire actually reflected composers' own ambiguous attitudes toward the use of folk music in contemporary art music. In fact, in terms of the development of art music, the use of folk music elements in art music compositions was supported ideologically at that time as tool that bound together two ideological currents that composers were compelled to follow in Soviet Estonia. In his article on Veljo Tormis's music, Jaan Ross summarizes these currents as follows: "One of these exhorted them [the composers] to develop the national origin of their composition style as a requirement of ensuring cultural continuity, while the other subjected their work to the doctrine of socialist realism - courtesy of the Soviet occupation regime." ${ }^{37}$ However, opinions about the more concrete meaning of this "national origin of the composition style" and its possible manifestation through the use of folk tunes varied from composer to composer. In this respect, one of the most crucial aspects of this "battle" around the use - or otherwise - of folk music idioms concerned the distinction between two different layers of the Estonian oral song tradition, the older and the newer. As the ethnomusicologist Janika Oras has concluded, the earlier oral song culture, the regilaul or runosong, is part of the common oral song tradition of the Baltic-Finnic peoples. In terms of its music, "runosong is characterised by linear, monophonic thinking. The repeated narrow-range melody of regilaul is comprised of

35 Veljo Tormis (1930-2017) is considered to be one of the most significant composers of choral music of the later twentieth century. His music is drawn on "the integral use of regilaul, the ancient runic song of Estonia, as compositional material. Other composers have used this song, but the manner in which Tormis uses regilaul, that is, preserving melodies intact, without traditional development is a hallmark of his style." Mark Lawrence, "Veljo Tormis and Urve Lippus: A Legacy," Res Musica 9 (2017): 93. More on Tormis' musical idiom see Jaan Ross, "Veljo Tormis and Minimalism: On the Reception of His New Musical Idiom in the 1960s," Res Musica 9 (2017), 109-118. About how and where did Tormis discover folk-song see Veljo Tormis. Lauldud sõna/The Word was Sung. [Transcribed by Urve Lippus, based on recordings and notes.] Translated by Harry Mürk (Tallinn: Eesti Köitekunstnike ühendus, 2008 [2000]).

36 Urve Lippus, "Folkloor ja taidlus," ["Folklore and amateur activity,"] Keel ja Kirjandus, no. 8 (1977): 508.

37 Jaan Ross, "Veljo Tormis and Minimalism: On the Reception of His New Musical Idiom in the 1960s," Res Musica 9 (2017), 109. 
one or two phrases, the rhythmic units in a phrase correspond to a syllable." ${ }^{38}$ This was precisely the earlier layer of the Estonian oral song tradition that was primarily championed by the ethnographic folklore ensembles in (late) Soviet Estonia (such as Hellero and Leegajus, both established in 1971), and a phenomenon that might be related to a kind of Estonianness when used in art music by a composer. The use of the newer layer of the oral song tradition, on the other hand, was the subject of very harsh criticism (as is clear from Kuldar Sink's writings, which will be considered later in this article). In musical terms, the newer layer of the oral song tradition refers to the end-ryhymed and stanzaic music that had "evolved during the $17^{\text {th }}-18^{\text {th }}$ centuries following European examples, and by the second half of the $19^{\text {th }}$ century this had replaced regilaul in most parts of Estonia." 39 It is precisely these activities of estrada-like folklore ensembles performing the (distorted version) of either older or newer folk music to which Urve Lippus refers at the end of her report on the above-mentioned meeting of Composers' Union folk music committee: "Advocacy of the standardized and eclectic pseudofolkloristic art was deplored [by the committee] for compromising both the performer [musicians and/or dancers] and the authentic folklore itself." ${ }^{40}$ Thus, in discussing the use of folk material in contemporary classical compositions in the late Soviet era, one should consider primarily the influence of the movement of the ethnographic folklore ensembles which dedicated their activities largely to the runosong tradition. Rather than the use of exact melodies or tunes, however, the influence of this tradition on the contemporary Estonian music of the time was manifested more indirectly through the imitation of the narrow-range melodies of the regilaul and their typical rhythmic units.

\section{Pop and Rock Music: Rein Rannap and Erkki-Sven Tüür}

Like the younger generation of composers in Russia who came of age in the 1970s, many Estonian composers were profoundly interested in popular music and the contemporary progressive rock movement. ${ }^{41}$ As in Western countries, these movements were mainly associated with youth culture and involved a certain element of social protest. At the same time, in Estonia they were also related to national ideas, as manifested in the use of classical and contemporary Estonian poetry.

The influences of pop and rock music on contemporary classical music can be most clearly illustrated through the activity of two composers, Rein Rannap (b. 1953) and Erkki-Sven Tüür (b. 1959). As members of the Estonian Composers' Union from 1979 and 1985 respectively, they may both be considered to be professional classical

38 Janika Oras, "Favourite Children and Stepchildren: Elite and Vernacular Views of Estonian Folk Song Styles," Res Musica 9 (2017): 27.

39 Oras, "Favourite Children," 27.

40 Lippus, "Folkloor," 509.

41 In Russia many of these composers "had a deep interest in popular music, especially American jazz of the 1950s and 1960s, the contemporary progressive rock movement, and recent jazz-rock fusion experiments." Schmelz, Such freedom, 296. Contrary to the Russian experience, however, jazz remained relatively untapped by composers of classical music in Estonia during the late Soviet era. There are, however, exciting examples of ensembles combining folk music and jazz in Estonian music at the time, e.g. Collage, Hõim. Also, the purest example of the eclectic combination of medieval music idioms with pop and jazz of the 1960s and 1970s concerns Olav Ehala's film music for Don Juan in Tallinn ("Don Juan Tallinnas," a musical comedy, 1971). 
composers - a term which then had a far more concrete meaning than in the 2000 s. $^{42}$ However, since the very beginning of their careers, the activities of both Rannap and Tüür have revealed rather mixed identities: on one hand, both of them are known as interpreter-composers; at the same time, however, since as early as the late 1970s their musical oeuvre has blurred the boundaries between different musics; moreover, their careers reflect an oppositional attitude toward the Soviet system that can be illustrated through their activities in two of the more influential (progressive-)rock bands of the time: Ruja and In Spe.

Ever since the 1970 s Rein Rannap has been - and still is - one of the most outstanding figures in Estonian musical life, highly acclaimed by both art and popular music audiences. Trained as a classical pianist, ${ }^{43}$ it was at the beginning of the 1980 s that he established a new concert format in Estonia by performing his improvisations on the concert stage, mixing the styles of classical, pop and jazz music. ${ }^{44}$ At the same time Rannap was a song writer and keyboard player in the rock band Ruja, which he had founded as far back as 1971. Considered to be the most famous Estonian rock band of all times, ${ }^{45}$ much of its activity was associated with protest against the Soviet system. In this context, one of the best-known songs from Ruja's repertoire, entitled Yesterday I Saw Estonia (Eile nägin ma Eestimaad), was composed in 1981. Of particular importance to the present discussion is the fact that this song includes a guitar solo, an instrumental interludium, which is an exact quotation from a well-known, symbolic Estonian piece of classical music - Homeland Tune (Kodumaine viis). Composed for piano by the Estonian national composer Heino Eller in 1918, the importance of Homeland Tune for the Estonians is comparable with that of Finlandia by Jean Sibelius for the Finns. ${ }^{46}$ In view of this, it is worth noting that this brief but telling mixture of rock and classical music in Yesterday I Saw Estonia is not intended in any way as a contradiction, but rather as a happy synthesis of otherwise different traditions. Moreover, the inclusion of Eller's music undoubtedly serves to underline the national sentiment of the lyrics of the song: penned by the Estonian contemporary poet Ott Arder (1950-2004), these evoke patriotic feelings describing contemporary Estonian landscapes and people. At the same time, the text serves as a paraphrase of the well-known poem by national poet Juhan Liiv (1864-1913), which dates from as early as 1904.

42 After graduating from Tallinn Conservatory with a composer's diploma, in Soviet times a young composer was expected to join the Composers' Union, which gave him or her more guarantees in social position and income. The list of the Union's members from that period includes several personalities who had a composer's diploma, but whose musical activities included different fields of music.

43 Rein Rannap graduated as a pianist from Tallinn Conservatoire in 1977 and completed his postgraduate studies at the Moscow State Conservatoire in 1979. Already during his studies, Rannap had gained some international acclaim for his performance of classical works: in 1973 he was awarded the first prize at the Estonian pianists' competition, and in 1976 he was awarded a diploma by the International Bach competition in Leipzig. In 1978 he released his first album, an LP with the music of Johann Sebastian Bach.

44 Two albums with his piano improvisations were released as LPs in 1983 (Melodiya, C60 19989) and 1986 (Melodiya, C60 23881004).

45 Ruja was active from 1971 till 1988, though with some pauses and changes of players. The reasons for their fame and recognition depended on both musical aspects (including the combination of elements from pop, rock and progressive rock, and the professional background of the musicians), as well as on the use of high quality lyrics that often carried some national message.

46 Homeland Tune is also known as a piece for string orchestra, orchestrated by Eller in 1953. It is the last piece from the Eller's cycle Five Pieces for String Orchestra (Viis pala keelpilliorkestrile). In addition to the guitar solo that appears in the middle of the song, Ruja's recorded version of Yesterday I Saw Estonia uses a short intro of the Homeland Tune played by the strings. 
While the song Yesterday I Saw Estonia serves as an example of the use of classical music in rock, the opposite case can be illustrated by the music of Raimo Kangro (1949-2001), Igor Garšnek (b. 1958), and Erkki-Sven Tüür. Exposing the biography and music of Tüür to closer scrutiny, we may conclude that the use of elements from rock music in the Estonian classical music of the late Soviet era also served as an attempt to broaden the range of expressive means considered by the academic world, as has already been discussed above in relation to early music movement.

Today Erkki-Sven Tüür is the most outstanding composer of his generation internationally, mainly owing to his orchestral music, which includes nine symphonies and several instrumental concertos. Whereas Rannap began his career as a classical pianist, Tüür was originally a rock musician. Even in his last year at the conservatory as a composition student in 1983, when asked about his musical role models, Tüür mentioned rock artists such as Jethro Tull, King Crimson, Genesis and Mike Oldfield. ${ }^{47}$ Research into Tüür's musical activities also highlights his background as a rock musician, including the fact that from 1976 till 1983 he was the leader of an acknowledged progressive-rock ensemble in Estonia, In Spe. In that band, he used a number of acoustic instruments, including violin, cello and recorders, alongside traditional electric rock music instruments. Conversely, in his later orchestral works - in his "classical" compositions - one can recognize the rhythms and "energies" traditionally attributed to rock music, though never in an eclectic manner. When questioned about the influences of different musics, Tüür often refers to the unity of musical communities in Soviet times. For example, according to Tüür, it was the general spiritual atmosphere in Estonia at that time that prompted the use of old, i.e. early music instruments in his compositions. More precisely, quite a variety of sources had an impact on his oeuvre, including Arvo Pärt's music in tintinnabuli style, the activity of Hortus Musicus, non-public lectures on religion and early cultures by the theologian and priest Einar Laigna, and acquaintance with a young musicologist Toomas Siitan, who was interested in early music. Together with some friends Tüür also sang early-Christian monody, sometimes even at the Tallinn Roman Catholic Church. ${ }^{48}$ These impulses affected not only the instrumentation of Tüür's art music, but also his musical style, bringing in the diatonic scales, melodic figures and rhythm-patterns typical of early music. ${ }^{49}$ Tüür's interest in very different kinds of musical sources is also exemplified in his entry in a booklet about Estonian composers published in 1988 in the framework of the Estonian Music festival. Here he writes: "I am 29, that is officially a young composer. I alternate between the labile ground of the radicalism of the avant-garde and post-modernistic tolerance, while at the same time being influenced by the gamelan of Bali, coriac drum sound and early Christian monody. I have never taken summer courses in Darmstadt, nor improved my knowledge at IRCAM, nor won the Prize of Rome." ${ }^{0}$

47 Peeter Tooma, "Levimuusika puudutusi. Vastab Erkki-Sven Tüür," ["Touched by popular music. Interview with Erkki-Sven Tüür,"] Sirp ja Vasar, June 10, 1983,13.

48 Anu Paulus, "Eesti nüüdismuusika ajaloolistele pillidele vanamuusika ansambli Hortus Musicus repertuaari näitel" [Estonian Contemporary Music for Historical Instruments Based on the Repertoire of Early Music Ensemble Hortus Musicus. ], (Master thesis, Estonian Academy of Music and Theatre, 2009).

49 The most outstanding compositions in this respect include his oratorio Ante finem saeculi (composed in 1985, revised 1986) and his Second symphony (1987). Available on Erkki-Sven Tüür. Oratorio Ante finem saeculi for soloists, mixed choir and orchestra. Symphony No. 2 for symphony orchestra and tape, Finlandia Records CD, 4509-95579-2 (1994).

50 Mare Põldmäe, ed., Estonian Composers 1988. Estonian Music Festival 1988 booklet (Tallinn: Estonian Republican Department of the USSR Music Fund, 1988), 35. 
Despite the somewhat sarcastic nature of this statement, Tüür's words also reveal the significant change that had taken place in public - official - discourse on music in the course of the Soviet period: finally, under the politics of perestroika, composers felt free to discuss avant-garde music as well as Christian monody in a positive light, at the same time pointing to their travel restrictions and their rare contact with Western colleagues.

\section{Kuldar Sink on Non-Western musical Cultures and Issues Related to Folk Music}

Interest in non-Western musical cultures was growing significantly in Estonia during the 1970s. This can be noticed in the spread of radio programmes on the topic as well as in articles published in the press, and, most importantly, through the reflections of non-Western traditional music in art music compositions. In order to investigate the sources of such interest, the activities of Estonian composer Kuldar Sink will be considered, particularly his series of articles on the traditional music of the peoples of Central-Asia and the Caucasus, which were published in the Estonian cultural press around the year 1980. There are a number of reasons for studying these texts. To begin with, it was the first time in Estonia that anyone had approached non-Western traditional music cultures, describing and analysing them in an academic manner and with scholarly ambitions. As such, Kuldar Sink's approach in his studies of this repertoire coincided with those related to the Estonian folk music revival discussed above. Secondly, the content of these articles reflects the ideological basis of Sink's own musical output, at the same time contextualizing the influences of non-Western musics present in the music of other composers at the time..$^{51}$ Finally - and perhaps in a rather unexpected context - these texts include quite a harsh criticism of the cultural and political situation of the Soviet system in their discussion of the topics of nationalness in music and the difficulties surrounding the use of folk tunes in art music compositions.

Whereas Rannap and Tüür were definitely part of a younger generation of composers in the 1970s, Kuldar Sink (1942-1995) had already gained recognition as a composer in the late 1950 s. $^{52}$ Together with Arvo Pärt, Veljo Tormis, Jaan Rääts and Eino Tamberg, Sink was one of the most innovative composers of that decade in Estonia: in the 1960s he was swept along by contemporary trends in music such as neoclassicism, serialism, collage and aleatorics. Then, as with Pärt and Tormis - as a result of an inner need - Sink's musical language changed significantly in the mid-1970s. From then on, Sink's works often relied on musical idioms associated with the music from "the East", primarily from Central-Asia and the Caucasus. However, contrary to

51 Together with Kuldar Sink, two other composers in late-Soviet Estonia were particularly inspired and influenced by non-Western musics: Sven Grünberg (b. 1956) and Peeter Vähi (b. 1955).

52 Sink graduated from the Tallinn Music School in music theory in 1960 and flute in 1961, also studying composition under Veljo Tormis. From 1961-1966 he continued his composition studies at the Leningrad Conservatoire, a fact that merits some explanation. In the 1960 s, in fact, it was not very common for Estonian composers to study composition abroad. The only thing that Sink underlined later as a reason for his Leningrad studies was his Christian background. Kuldar Sink was born into a Christian family; his father had been a priest and his mother a church musician, known also for her primarily sacred vocal compositions. These reasons alone were enough for Sink to abandon the idea of studying composition at the Tallinn Conservatory. 
the experience of Pärt (and, to a certain extent, of Tormis as well), the fact of dedicating himself to this type of source material brought him no disapproval among Soviet officials. Moreover, unlike the severe restrictions on travel to Western countries, the opportunities for travel across the Soviet Union were both plentiful and affordable at the time. Thus, combining these favourable practical factors and his own musical interests, Sink was able to make several trips to Central-Asia and the Caucasus from the late 1970 s till the mid 1980s. ${ }^{53}$

The composer himself explained the purpose of these trips as follows: "I consciously enhance the expansion of my listening experience. If one has the experience of listening to the music of many peoples, one may be able to listen more objectively to the music of one's own country. [...] Only then does it become possible to assess oneself correctly, by taking a look from larger perspective. That is my musical-political program." 54 The preceding quotation dates back to the autumn of 1977 and originates from the first newspaper article published in a series about peoples and their music in the countries of Central-Asia and the Caucasus. From 1977 to 1982 Kuldar Sink contributed to the Estonian cultural weekly Sirp ja Vasar and the journal Teater. Muusika. Kino, publishing altogether eleven articles on this topic. ${ }^{55}$ In these texts, the cultural legacy of seven different countries from these regions was discussed, with the primary emphasis on their traditional music: Kyrgyzstan, Kazakhstan (Central-Asia, focusing on Kirghiz and Kazakh folk music), Georgia (plus two extra articles about Svanetis), Armenia, Dagestan and Azerbaijan (in the Caucasus). ${ }^{56}$ Reflecting the official cultural and political positions of the publication, this series was dedicated to the $60^{\text {th }}$ anniversary of the October revolution and had the task of providing an overview of the music cultures of the peoples of the USSR. ${ }^{57}$ Indeed, this was the very first time that the music of these distant regions had been discussed in Estonia's (printed) media ${ }^{58}$ at such length or in such a scholarly manner.

Sink concludes his observations by pointing to a more general tendency in the development of folk music which can be applied to many regions - the general westernisation of music cultures. Exemplifying his thoughts with Armenian, Georgian and Kazakh

53 With regard to practical matters, it is worth mentioning, that as a member of the Soviet Estonian Composers' Union, it was possible to apply for creative travel support. As a result of doing so, during these trips Sink was appointed on some occasions as a correspondent and had to attend official meetings with other Soviet colleagues or representatives of the authorities. Mostly, however, he traveled by himself - "just me and my tent", as Sink often recalled. Thus, among Estonians, his trips to Central Asia are also known as his peripatetic journeys. See Ruth Alaküla, "Intervjuu Kuldar Singiga. Salvestatud 1992. aasta augustis," ["Interview with Kuldar Sink, recorded in August 1992"], Teater. Muusika. Kino, no. 10 (1997): 40.

54 Kuldar Sink, "Eestlased ja kirgiiside muusika (ühed ülimalt subjektiivsed mõtted mõttevahetuse korras),” [„Estonians and Kyrgyz's music (some highly subjective thoughts for the exchange of views)."] Sirp ja Vasar, November 18, 1977, 12.

55 Ten articles were published in the cultural newspaper Sirp ja Vasar (from 1977 to 1979) and one in the magazine Teater. Muusika. Kino (in 1982).

56 Side by side with more general topics (picturesque geographical descriptions, historical events, the introduction of religious beliefs and customs, linguistic issues, etc.), more attention was paid to the music of these people. Sink writes about well-known musicians, folk instruments and genres of music.

57 As such, these articles were paired with a series of music programs Sink made for the Estonian Radio, broadcast regularly about a week after the written texts. However, typically of this period, the radio programs were not recorded, and we cannot know what music was broadcast; however, most of it probably coincided with music mentioned in the articles.

58 As for broadcasts, a few years earlier, in 1974 a series on the traditional music of distant countries had started on Estonian radio (Kauged rahvad muusikas). In these broadcasts, composer and music historian Leo Normet gave an insight into the traditional music and cultures of different regions, located as far from each other as Tahiti, Morocco, Iceland, Latin-America, etc. Compared to Sink, however, Normet's broadcasts were more literary and entertaining, with rich musical illustrations, but without any scholarly ambition. 
folk music, Sink indicates the vanishing nature of these authentic, valuable traditions. Let us give as an example his thoughts on Kazakh folk music, more precisely concerning the situation in the former capital, Almaty: "It seems that they have started to make something like great art out of folk music. It is a nice idea, but unfortunately, they have totally forgotten all the anonymous folk musicians who actually carry on the traditions in village communities. The aim of this kind of urbanized [folk] music, made in the name of art, is mostly to introduce Kazakh music outside their republic." ${ }^{59}$ It is precisely here that Sink leads up to the topics that are of most relevance to of our discussion - firstly, to draw parallels between the traditional musics of Central-Asia and the Caucasus with Estonian folk music, and secondly, to address the problematic issues surrounding nationalness in music and its possible relations to the use of folk music in classical works. As mentioned above, the official cultural politics of the Soviet Union supported the view that some kind of national individuality is required of a composer. In particular, it was expected that composers of the national Soviet republics would demonstrate some specific qualities in their music that are common to their own national (Estonian or other) spirit or temperament. To this end, the direct use of folk tunes and/or national themes was seen as the ideal choice. However, this demand was rejected by several Estonian composers, including Kuldar Sink. There were at least two different reasons for such a reaction. On one hand, Estonian composers wanted to belong to and be seen as part of a wider European cultural landscape, and therefore they did not feel any urge to be 'nationalistic' per se. ${ }^{60}$ The second reason is more multi-faceted. As we can conclude from Sink's articles, it was seen as improper to present this westernised form of folk music as part of an authentic traditional heritage. And, for the same reason, neither should it be used in art music. Sink writes: "We may feel some 'homesickness' for this vanished culture, but the births, vanishings and blending of different cultures have taken place in all times and peoples from the Assyrians to the Indians." ${ }^{11}$ In an Estonian context, by this "vanished culture" Sink is referring to the runosong tradition discussed above, which, due to the Germanic style of choral singing (Liedertafel) - which Estonians now incorrectly believed to be Estonian had already died out slowly a long time before. Sink goes on: "All cultures are equal, one cannot place them one upon another, they should be observed as if side-by-side. What am I fighting against? [I am fighting] against pseudo-Estonianness, against European [i.e. art] music that pretends to be Estonian-like. Also, it is ridiculous to give birth once again to Estonian folk music culture 'just for fun'. Let us become cosmopolitans! Leave all the 'Uku' products ${ }^{62}$ for tourists!'”3

The ambiguity of Kuldar Sink's attitude toward the use of folk music in contemporary music is also manifested in his own compositions. As we have seen, on one hand

59 Kuldar Sink, "Küü traditsioonides praegu [Kasahhi rahvamuusikast]," ["Nowadays traditions of kyui. About Kasakh folk music",] Teater. Muusika. Kino, no. 9 (1982): 74.

60 Anu Veenre, "Changes in Estonian Music and Composer's Identity in the Last Decade of the Soviet Period," in Music and Identities: The Baltic Sea Region in the 21st Century; New Approaches to Music Analysis. Proceedings from 42nd International Baltic Musicological Conference. Mūzikas akadēmijas raksti VIII, ed. Baiba Jaunslaviete (Rìga: Jāzepa Vìtola Latvijas Mūzikas akadēmija, 2011).

61 Sink, "Eestlased," 12.

62 "Uku" was a well-known handicraft company in Estonia at the time, producing beautiful ethnographic textiles. However, the products of "Uku" had little to do with the authentic handicraft traditions.

63 Sink, "Eestlased," 12. 
Sink clearly condemns the combining of different traditions. On the other hand, from the late 1970s onward his own compositions do actually reflect idioms characteristic of non-Western (traditional) music. What seems to matter for Sink in this context is "how" this process of combining different traditions is handled and how the final outcome should be received and understood: One cannot present two different traditions simultaneously, within or inside each other. Rather, both of these traditions will be transformed through this process of combination. As a more concrete example, let us examine Kuldar Sink's piano sonata trilogy Mountains and Men (Mäed ning inimesed), composed in May 1977 after a period of creative silence. ${ }^{64}$ The piece was inspired by his hike to lake Issyk Kul, the lake located in the northern Tian Shan mountains in Eastern Kyrgyzstan. ${ }^{65}$ The description of the music on the back of its LP jacket illustrates the range of different musics Sink alludes to in this cycle as well as the synthesizing objective of his approach: "In this work, styles which differ widely both temporally and spatially, such as early medieval music, aleatory music, jazz, Kirghiz and Chinese music, are blended, although not by means of collage. This is a reflection of what the human ear catches individually and of what is drawn from collective memory." ${ }^{\circ 6}$ Thus, Kuldar Sink's musical world incorporates elements from very many different traditions and musics. Among the listeners his music definitely evoked different musical cultures, but the composer himself did not want to present this material as something exotic. Instead of using national material (as supported by official politics) or forming a European identity (as desired by many of his contemporaries), Sink was interested in combining musics from even more distant regions of the world. At the same time, his use of diatonic scales, static dramaturgy, rhythmic patterns, and tunes that are easily associated with early music, folk, and/or non-Western traditions alike allows us to see his compositions as part of a more general trend in Estonian music in the late Soviet era - a trend manifested in polystylistic thinking.

\section{Conclusion}

In Estonian music history, the 1970 s are seen as a decade when a new and very influential group of young composers came of age. Many of their creative preoccupations at the time concerned a type of polystylistic writing which manifested itself in the use of elements originally associated with other musical realms, such as early music, folk music, elements of pop-rock, and/or non-Western traditional music. The compositional-technical approach to the polystylism of these composers differs from that of their older colleagues in the preceding decade, and marks a significant shift in

64 The trilogy Mäed ning inimesed consists of Piano sonatas no. 2-4; Kuldar Sink's interest toward Arabic maqams are also reflected in his song cycle The Songs of Death and Birth (Surma ja Sünni laulud, lyrics by Federico Garcia Lorca) for mezzo soprano and chamber ensemble, composed in 1985/1986.

65 Sink picturesquely describes the surroundings of the lake: "An azure mirror of the lake between snow-capped mountains which, like sentinels, surround you from each side - here everyone is a rider from birth: whole villages on horses and donkeys; here everyone knows how to play the khomyz, the favourite national instrument. Without this skill you are even not thought to be man. Well, this is an idyllic image of Issyk Kul, situated at the attitude of 1,609 meters." Kuldar Sink, Sonata-trilogy Mäed ning inimesed, Kalle Randalu, piano, Melodiya LP, C10 23053007 (1985).

66 Kuldar Sink, Sonata-trilogy. 
polystylistic thinking around the mid-1970s. In particular, instead of using elements relating to the historical layers of the classical music legacy, Estonian polystylistic music of the late Soviet era and beyond draws primarily on contemporary sensibilities. Indeed, the allusions to early music, Estonian folk music, elements of pop-rock, and/ or non-Western traditional music seen in many of the new compositions of the era may all be interpreted as reflecting the influence of the trends that surrounded composers in the contemporary musical life of the time. Thus, the examples of early or folk music idioms also serve as references to contemporary fields of music. Furthermore, compared with the 1960s, the polystylistic approach of the late Soviet period and beyond definitely favours the symbiotic use of elements in new compositions over eclecticism.

In addition to researching the late Soviet era, this article also had the goal of contributing to national music history writing as approached from the perspective of cultural musicology. To this end, the polystylistic writing of the 1970s and 1980s was also discussed as a cultural phenomenon reflecting the socio-political context and processes in the musical life of the time. In this respect it can be concluded that blurring the boundaries between different musics in late Soviet Estonia served as a tool for bringing the different musical communities of the time closer together. In musical terms, and with respect to the developments in art music, this "blurring process" manifested itself in a form of polystylistic writing that favoured the symbiotic use of different elements in new compositions over processes of juxtaposition. With regard to musical life, the unity of the different musical communities could be seen in their shared attitude - a sort of disaffection - towards the Soviet system, an attitude due largely to the ideological pressure placed by the authorities on the arts.

In fact, regardless of the restrictions at official level, religious topics were "in the air" among the musicians and composers of the time. The activities of early music enthusiasts (including Hortus Musicus), in particular, served as a distinct kind of spiritual opposition in Soviet society at the time. Contemporaneously, the folk music movement, opposed the Soviet system with regard to the problematic issues surrounding nationalness in music - an ideological current that folk ensembles and composers were forced to follow in their activities and in their works at the time. In this respect, it was the earlier layer of the Estonian oral song tradition, runosong, which was primarily championed by the ethnographic folklore ensembles (Hellero and Leegajus) and viewed as a phenomenon that might be related to a kind of Estonianness when used by composers of art music. The use of the newer layer of the oral song tradition, on the other hand, was the subject of harsh criticism. In this article these issues were examined through the writings of Kuldar Sink - a composer whose involvement in non-Western traditional musics also provided him with the opportunity to consider the potential relations between European (classical) music and other musical realms and the possibility of combining them. Finally, with regard to (progressive) rock music, another type of protest against the Soviet system can be noted: the national ideas as manifested in the activity of the ensembles Ruja and In Spe, for example, mainly arose from their yearning for a more liberal spiritual atmosphere in the era, while simultaneously referring to the need for closer contact with their Western colleagues. 
Studies in early music, folk, rock, and non-Western musical traditions were all supported by the state in their own way, yet a closer involvement in these fields also made it possible for musicians and composers to alienate themselves to a certain extent from the Soviet system. As an act of deterritorialization, involvement with these musics in Estonia was about exploring new (musical) territories - the imaginary "elsewheres" put forward by Alexei Yurchak in his research on the late Soviet era - that offered an escape from the Soviet world of constant control and dictate, a life in vnye. The concept of "unofficial" as proposed by Peter Schmelz for studying the musical Thaw, however, must be applied to the late Soviet Estonian context only with caution. Viewed in musical terms as reflecting early music, folk, pop rock, and/ or non-Western music traditions, most of the Estonian contemporary classical music of the period, in fact, preferred more consonant sounds. Thus, this music was much more easily accessible than that of the 1960s, and it did not contradict the doctrine of socialist realism per se. With regard to the "social dimension" of the arts, the music discussed in this article was typically purchased by the state, performed under the auspices of the Philharmonic Society, and published by government-run firm, thus making it - in principle - as official as possible. However, as Kevin Karnes has summarized the concept, "unofficial music was not a manifestation of dissent-or even, necessarily, of protest. It simply stood outside the system of state-controlled musical patronage." ${ }^{67}$ Seen from this perspective, it can be concluded that, rather than any practical matters, it was the general manner of thinking about the essence and mechanisms of the arts and cultural life that differed "unofficial" music from the official Soviet view, and which thus alienated many musicians and composers from the Soviet system in Estonia during the 1970s and 1980s.

\section{Bibliography}

Alaküla, Ruth. "Intervjuu Kuldar Singiga. Salvestatud 1992. aasta augustis." ["Interview with

Kuldar Sink, recorded in August 1992.”] Teater. Muusika. Kino, no. 10 (1997): 38-44.

Baley, Virko, and Sofia Hrytsa. "Ukraine." Grove Music Online. Accessed March 25, 2018. http://www.oxfordmusiconline.com/grovemusic/view/10.1093/gmo/97815615 92630.001.0001/omo-9781561592630-e-0000040470.

Cook, Nicholas, and Anthony Pople, eds. The Cambridge History of Twentieth-Century Music. Cambridge; New York: Cambridge University Press, 2004.

Dolidze, Leah, Christian Hannick, Dali Dolidze, Grigol Chkhikvadze, and Joseph Jordania. "Georgia." Grove Music Online. Accessed March 25, 2018. http://www.oxfordmusiconline.com/grovemusic/view/10.1093/gmo/9781561592630.001.0001/ omo-9781561592630-e-0000042156.

Hunt, Kadri. "Retk aednike juurde. Hortus Musicus 30." ["Expedition to the gardeners. Hortus Musicus 30."] Muusika no. 9 (2002): 2-9. 
Hortus Musicus webpage. Accessed June 30, 2018. https://concert.ee/kollektiiv/ hortus-musicus/.

Karnes, Kevin C. Arvo Pärt's Tabula Rasa. Oxford keynotes. New York: Oxford University Press, 2017.

Lawrence, Mark. "Veljo Tormis and Urve Lippus: A Legacy." Res Musica 9 (2017): 93-101.

Lippus, Urve. "Folkloor ja taidlus." ["Folklore and amateur activity."] Keel ja Kirjandus, no. 8 (1977): 508-509.

Oras, Janika. "Favourite Children and Stepchildren: Elite and Vernacular Views of Estonian Folk Song Styles." Res Musica 9 (2017): 27-44.

Paulus, Anu. "Eesti nüüdismuusika ajaloolistele pillidele vanamuusika ansambli Hortus Musicus repertuaari näitel." [Estonian Contemporary Music for Historical Instruments Based on the Repertoire of Early Music Ensemble Hortus Musicus.] Master thesis, Estonian Academy of Music and Theatre, 2009.

Põldmäe, Mare. "Mõeldes möödunud muusika-aastale." ["Thinking about the yesteryear in Music."] Teater. Muusika. Kino, no. 2 (1982): 76-79.

Põldmäe, Mare, ed. Estonian Composers 1988. Estonian Music Festival 1988 booklet. Tallinn: Estonian Republican Department of the USSR Music Fund, 1988.

Remmel, Anti. "(Anti)-Religious Aspects of the Cold War." In Behind the Iron Curtain: Soviet Estonia in the Era of the Cold War. Tartu Historical Studies, Volume 5, edited by Tõnu Tannberg. Frankfurt am Main: Peter Lang Verlag, 2015, 359-391.

Ross, Jaan. "Veljo Tormis and Minimalism: On the Reception of His New Musical Idiom in the 1960s." Res Musica 9 (2017): 109-118.

Schmelz, Peter J. Such freedom, if only musical. Unofficial Soviet Music during the Thaw. Oxford: Oxford University Press, 2009.

Siitan, Toomas. "Vana muusika uues muusikas." ["Old music in new music."] Teater. Muusika. Kino, no. 6 (1984): 30-37.

Sink, Kuldar. Sonata-trilogy Mäed ning inimesed. Kalle Randalu, piano. Melodiya LP, C10 23053007 (1985).

Sink, Kuldar. "Eestlased ja kirgiiside muusika (ühed ülimalt subjektiivsed mõtted mõttevahetuse korras).” [„Estonians and Kyrgyz's music (some highly subjective thoughts for the exchange of views)."] Sirp ja Vasar, November 18, 1977.

Sink, Kuldar. "Küü traditsioonides praegu [Kasahhi rahvamusikast]." ["Nowadays traditions of kyui. About Kasakh folk music.”] Teater.Muusika.Kino, no. 9 (1982): 70-74.

Stefanija, Leon, Jurij Snoj, and Svanibor Pettan. "Slovenia." Grove Music Online. Accessed March 25, 2018. http://www.oxfordmusiconline.com/grovemusic/view/10.1093/ gmo/9781561592630.001.0001/omo-9781561592630-e-0000040472.

Tannberg, Tõnu. "Foreword." In Behind the Iron Curtain: Soviet Estonia in the Era of the Cold War. Tartu Historical Studies, Volume 5, edited by Tõnu Tannberg. Frankfurt am Main: Peter Lang Verlag, 2015, 7-14.

Tooma, Peeter. "Levimuusika puudutusi. Vastab Erkki-Sven Tüür." ["Touched by popular music. Interview with Erkki-Sven Tüür.”] Sirp ja Vasar, June 10, 1983.

Tormis, Veljo. Lauldud sõna / The Word was Sung. [Transcribed by Urve Lippus, based on recordings and notes.] Translated by Harry Mürk. Tallinn: Eesti Köitekunstnike ühendus / [Tallinn: Folger Art], 2008 [2000] 
Tüür, Erkki-Sven. Oratorio Ante finem saeculi for soloists, mixed choir and orchestra. Symphony No. 2 for symphony orchestra and tape, Finlandia Records CD, 450995579-2 (1994).

Veenre, Anu. "Changes in Estonian Music and Composer's Identity in the Last Decade of the Soviet Period." In Music and Identities: The Baltic Sea Region in the $21^{\text {st }}$ Century; New Approaches to Music Analysis. Proceedings from 42nd International Baltic Musicological Conference. Mūzikas akadēmijas raksti VIII, edited by Baiba Jaunslaviete. Rīga: Jāzepa Vītola Latvijas Mūzikas akadēmija, 2011, 63-72.

Yurchak, Alexei. Everything was forever, until it was no more: the last Soviet generation. Princeton (N.J.); Oxford: Princeton University Press, 2006.

\section{POVZETEK}

V zvezi z glasbenim življenjem bi lahko povezanost različnih glasbenih skupnosti časa opazovali v njihovem skupnem odnosu - neke vrste nezadovoljstvu - do sovjetskega sistema, odnosu, ki je bil večinoma posledica ideoloških pritiskov oblasti na umetnost. Tako so bile ne glede na omejitve na uradnem nivoju religiozne teme v tem času "v zraku « med glasbeniki in skladatelji. Še posebej prizadevanja navdušencev za staro glasbo (med drugim ansambla Hortus Musicus) so služila kot jasna duhovna opozicija sovjetski družbi tega časa. Hkrati so gibanja za ljudsko glasbo nasprotovala sovjetskemu sistemu na ravni problematike, povezane z vprašanjem nacionalnosti v glasbi - ansambli za ljudsko glasbo in skladatelji so se bili v svojem delu prisiljeni podrejati temu ideološkemu toku. V članku so ta vprašanja preiskana na podlagi zapisov skladatelja Kuldarja Sinka, ki je prek ukvarjanja z ne-zahodno tradicijsko glasbo prišel do možnosti premišljevanja o zvezah med evropsko (klasično) glasbo in drugimi glasbami ter še posebej o možnostih njihovega povezovanja. $\mathrm{Ob}$ opazovanju progresivne rockovske glasbe je mogoče odkriti še eno obliko protesta proti sovjetskemu sistemu: nacionalne ideje, kakor jih je razbrati iz delovanja skupin Ruja in In Spe, so izšle iz želje po bolj sproščeni duhovni klimi, medtem ko so hkrati izražale potrebo po močnejših kontaktih s svojimi zahodnimi kolegi.

Država je na svoj način podpirala preučevanje stare glasbe, ljudske glasbe in ne-zahodnih glasbenih tradicij, toda bolj poglobljeno ukvarjanje s temi področji je glasbenikom in skladateljem omogočilo, da so se do določene mere odtujili sovjetskemu sistemu. Kot akt deteritorializacije je bilo ukvarjanje s takšnimi glasbami v Estoniji povezano z raziskovanjem novih (glasbenih) dežel - nekakšnih namišljenih »drugih dežel«, kakor jih poimenuje AleksejJurčak v svojih raziskavah poznega sovjetskega obdobja. Te so ponudile možnost pobega iz sovjetskega sveta, zaznamovanega s stalno kontrolo in diktatom, torej nekakšno življenje v vnye. Koncept "neuradnega", kakršnega je predlagal Peter Schmelz za študij glasbe v času politične "odjuge«, pa je potrebno uporabljati v zvezi s pozno sovjetsko Estonijo previdno. Šlo je namreč za splošno sprejeto mnenje o bistvu in mehanizmih umetnosti in kulturnega življenja, ki je "neuradno" glasbo razlikovalo od uradnega sovjestkega pogleda in ki je mnoge estonske glasbenike in skladatelje v 70 -ih in 80-ih letih odtujilo od sovjetskega sistema. 